Bulletin of Taras Shevchenko National University of Kyiv. Series "Psychology". № 2(12), pp. 10-15 (2020) УДК 159.923

DOI: https://doi.org/10.17721/BSP.2020.2(12).2
ISSN 1728-3817

(C) Taras Shevchenko National University of Kyiv,

Publishing and Polygraphic Center "Kyiv University", 2020

Ксенія Грузинова, асп. ORCID: 0000-0002-7800-1375

Київський національний університет імені Тараса Шевченка, Київ, Україна

\begin{abstract}
Дослідження спрямоване на визначення особливостей взаємозв'язку переконань особистості із психологічним благополуччям. Доводиться роль базових переконань як світоглядного чинника благополуччя, досліджуються особливості їхньої взаємозалежності в період пандемії. У дослідженні використано методи групового опитування і статистичної обробки. Емпіричним иляхом установлено наявність взаємозв'язків переконань у прихильності та справедливості світу, доброті людей і цінності "Я" із різними аспектами благополуччя.
\end{abstract}

Ключові слова: світогляд, аспекти благополуччя, пандемія, прихильність світу, справедливість світу, світоставлення.

Вступ. Нові умови соціальної реальності, викликані карантинними діями з метою запобігання розповсюдження вірусу COVID-19, допомогли знову усвідомити актуальність досліджень, пов'язаних із виявленням міри задоволеності особистості своїм життям, особливостей іiї психологічного благополуччя й позитивного функціонування. Виявлення чинників, які зумовлюють переживання благополуччя особистістю навіть в умовах, що певним чином обмежують свободу її дозвілля й активного соціального життя, в умовах соціальних змін, які змушують пристосовуватися до вимог зовнішнього середовища, $€$ нагальним завданням сучасних досліджень. Згідно із нашим переконанням, серед подібних чинників слід особливо зазначити роль світоглядних чинників - складових світогляду особистості, які можуть стати міцним особистісним фундаментом, що опосередковує психологічне благополуччя особистості навіть у мінливих і складних життєвих ситуаціях.

Основна мета пропонованої роботи полягає, поперше, у виявленні залежності особливостей психологічного благополуччя від світоглядних переконань, а також у визначенні взаємозв'язків переконань особистості з різними аспектами благополуччя. Другою частиною дослідницької мети $є$ виявлення особливостей виявлення переконань і благополуччя в контексті обмежень соціального функціонування в період пандемії.

Методи. Дослідження проводилося у формі письмового групового опитування респондентів. Як тестовий інструментарій під час дослідження застосовували шкалу базових переконань Р. Янова-Бульмана і методику діагностики суб'єктивного благополуччя особистості Р. М. Шаміонова, Т. В. Бескової. Результати опитування аналізувалися із використанням методів статистичної обробки даних.

Теоретичні основи дослідження. Наявні концепції психологічного благополуччя пропонують своє трактування цього явища і його змістовне наповнення. 3 одного боку, френомен благополуччя може трактуватися як суб'єктивна задоволеність особистістю власним життям, $з$ іншого - як повнота її самореалізації та позитивного функціонування. У рамках цього дослідження нас найбільше цікавить благополуччя в різних виявленнях, а саме те, які аспекти або види феномена благополуччя можуть стати об'єктом наукового вивчення і яким чином вони можуть бути обумовлені наявними в особистості переконаннями. Тому за концепцію, що лежить в основі дослідження, ми узяли структуру суб'єктивного благополуччя, запропоновану Р.М. Шаміоновим і Т. В. Бесковою. У результаті теоретичного й емпіричного дослідження ними було виокремлено такі п'ять аспектів благополуччя особистості: емоційне, екзистенційно- діяльнісне, его-благополуччя, гедоністичне і соціальнонормативне благополуччя [11]. 3 нашого погляду, безсумнівними перевагами цієї концепції можна вважати такі: по-перше, вона охоплює широкий спектр різних видів благополуччя; по-друге, не суперечить іншим концепціям психологічного благополуччя (можлива навіть ситуація одночасного прийняття дослідником кількох поглядів на природу феномена благополуччя), оскільки компоненти благополуччя, запропоновані Р. М. Шаміоновим і Т. В. Бесковою, є різними аспектами, видами або навіть сферами благополуччя, а не його змістовними структурними компонентами.

Як видно з теми дослідження, переконання особистості розглядається як світоглядний чинник психологічного благополуччя, тобто як компонент світогляду особистості, який визначає рівень ії̈ благополуччя. Безсумнівно, переконання особистості $€$ значущим компонентом індивідуального світогляду. Аналіз літературних джерел, присвячених проблематиці структури світогляду особистості, дозволяє зазначити центральне місце переконань у психологічній структурі явища світогляду, які можна навіть вважати "серцем" його змістового наповнення. В усіх представлених нижче концепціях світогляду зазначається значущість переконань особистості. Наприклад, у рамках різних теорій пропонується розглядати такі елементи світогляду: когнітивна, емотивна й настановча складові [10]; змістовний (представлений переконаннями особистості), ціннісний, структурний і функціональний аспекти [3]; метафрізика, стосунки із групою, ставлення до авторитету, локус відповідальності, суб'єктність, мінливість як компоненти світогляду [15]; світопереконання, "Я-розуміння", ставлення до себе і навколишнього світу [1; $3 ; 10 ; 15]$.

Саме поняття світогляду доцільно визначити як систему узагальнених поглядів на природу і суспільство, місце людини в ньому, загальні закономірності функціонування реального й ідеального світів, ставлення людей до навколишньої дійсності та себе, а також зумовлені цими поглядами переконання, ідеали і принципи пізнання [2].

Як стає зрозумілим із представленого вище трактування, явище світогляду нерозривно пов'язане із психічним феноменом ставлення. Ставлення $є$ суб'єктивною рисою відображення особистістю різних аспектів дійсності, світу, результатом взаємодії особистості з навколишнім середовищем. У роботах В. М. Мясищева ставлення розглядається як феномен, який відображає особливості зв'язку суб'єкта (особистості) зі світом (середовищем), а також як інтегральна позиція особистості. Сама особистість у такому випадку виступає своєрідною системою різних ставлень до світу [6]. 
Значною мірою така система ставлень до світу зумовлюється попереднім досвідом особистості, наявними в неї переконаннями і цінностями. Результатом процесу формування ставлень стає складне структурне утворення взаємозв'язків між особистістю і середовищем [5], яке, на нашу думку, і прийнято називати світоглядом. Таким чином, утворення певних ставлень особистості до світу і самої себе можна вважати, поперше, способом формування світогляду особистості, а по-друге, способом виявлення світогляду у вигляді конкретних переконань, дій, вчинків. На нашу думку, зв'язок феномена ставлення і переконань особистості в межах цілісного світогляду можна зобразити таким чином (рис. 1).

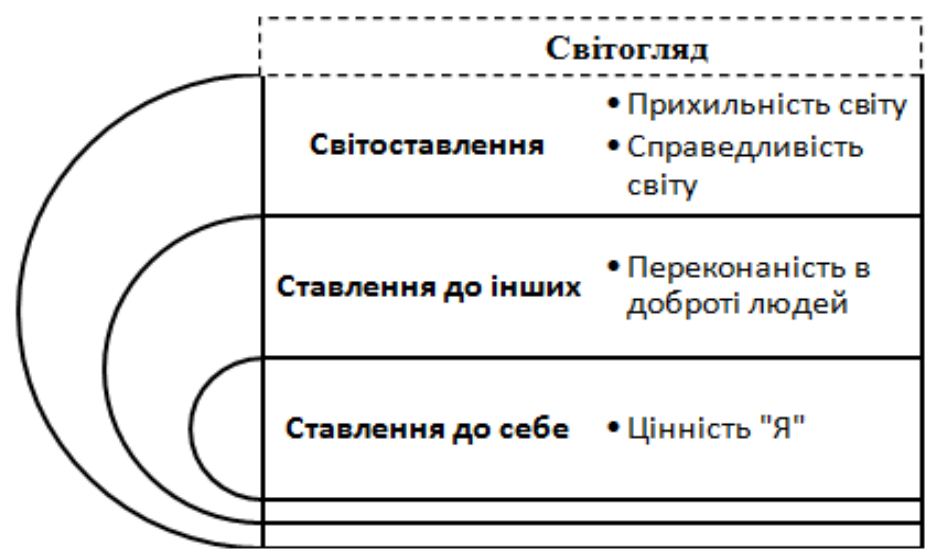

Рис. 1. Модальності ставлення як частина світогляду

У пропонованій схемі базові переконання особистості, які можна вважати світоглядними (відображають узагальнені погляди на суспільство, світ і самого себе, особливості функціонування реального й ідеального світів), відповідають трьом можливим модальностям ставлення: світоставлення, ставлення до інших і ставлення до себе. Усі означені модальності ставлення тут виступають як шляхи реалізації світогляду на практиці: світогляд $є$ джерелом і результатом взаємодії особистості зі світом, а ставлення - каналом, через який світогляд може знайти свій когнітивний, емотивний і поведінковий вияви. Наприклад, світоставлення (як частина цілісного світогляду особистості) може виявлятися у переконанні у справедливості світу і виконанні дій, що відповідають власним ідеалам справедливості (волонтерська діяльність, справедливі вчинки тощо).

Як було зазначено в меті дослідження, ще одним нашим завданням $€$ вивчення особливостей виявлення благополуччя в контексті обмежень соціального функціонування в період пандемії, оскільки необхідно враховувати особливості соціальної ситуації в дослідженнях, спрямованих на визначення чинників психологічного благополуччя особистості. Безумовно, карантин 2019-2021 років, упроваджений через пандемію вірусу COVID-19, і пов'язані з ним обмеження значною мірою вплинули на особливості життєдіяльності більшої частини населення.

У дослідженнях, присвячених визначенню особливостей благополуччя в період пандемії коронавірусу, було констатовано відмінності в переживанні щастя і зазначено, що стійкі тривалі стосунки з іншими і високий рівень соціальної активності, збережений навіть під час карантину, позитивно корелюють із переживанням благополуччя [4].

Було досліджено суб'єктивне благополуччя під час пандемії у зв'язку з використанням соціальних мереж і низкою інших чинників (оцінкою загрози вірусу для здоров'я, способами проведення дозвілля в період пандемії тощо). Було доведено, що визначними чинниками позитивного ефекту під час карантину слід вважати особливості та якість проведення часу в соціальних мережах та інтернеті загалом. Результати досліджень показали, що конструктивні способи проведення карантину (перегляд онлайн-курсів, фрільмів і читання книг) слід вважати позитивними чинниками психологічного благополуччя в період пандемії та карантинних обмежень, оскільки вони були пов'язані з переживаннями захоплення, зацікавленості, виникненням відчуття бадьорості тощо. У респондентів зазначалося зменшення рівня тривоги і нівелювання негативних прогнозів протягом переживання карантину (було помічено зменшення рівня тривоги стосовно стану здоров'я, змінилося ставлення до економічних наслідків пандемії на краще). Чинник наявності онлайн-комунікацій із друзями та близькими не мав відчутного зв'язку з переживанням щастя під час карантину [13].

Також у публікаціях за цією тематикою було визначено основні позитивні (ресурсні) і негативні чинники благополуччя в період пандемії. До позитивних чинників-ресурсів було віднесено психологічну гнучкість і оптимізм. До негативних короткотривалих стресорів було віднесено страх бути інфрікованим вірусом COVID-19, тиск 3MІ або звичайна нудьга, а також низка стресорів, вплив яких на благополуччя може бути доволі тривалим - психологічний ефект від економічних труднощів, складність профресійної самореалізації тощо в період пандемії [9].

В інших дослідженнях було доведено, що негативними чинниками благополуччя періоду пандемії $€$ економічні складнощі в родині, проблеми 3 академічною успішністю (у студентів) і наявність знайомих людей, які захворіли коронавірусною хворобою. Проживання в одному домі або квартирі разом з родиною і наявність постійного джерела стабільного доходу в сім'ї було визнано позитивними чинниками благополуччя, які допомагають зменшити інтенсивність переживання тривоги під час карантину [14].

Також було виявлено, що психологічний тиск, пов'язаний зі складною соціальною ситуацією пандемії, може виявлятися у зростанні тривожності та зниженому рівні психологічного благополуччя, переживанні астенічних емоцій і депресивних станів, тенденції до застосування копінг-стратегій уникнення і соціального відволікання [8].

Методологія. Об'єктом дослідження є психологічне благополуччя; предметом дослідження - переконання особистості як світоглядний чинник ії̈ психологічного благополуччя. Дослідницькі задачі полягають у такому: 
1) розкрити особливості взаємозв'язку аспектів благополуччя з переконаннями особистості;

2) з'ясувати наявність взаємозалежності рівня благополуччя від переконань особистості;

3) розкрити особливості виявлення різних аспектів психологічного благополуччя і переконань особистості в період соціальних обмежень, спричинених пандемією COVID-19.

Гіпотеза дослідження включає такі припущення:

- Переконання особистості, які відображають особливості її світоставлення (прихильність і справедливість світу), ставлення до інших (переконання в доброті людей) і до себе (переконання в цінності "Я") обумовлюють рівень психологічного благополуччя.

- Наявність переконань у прихильності та справедливості світу матиме позитивний зв'язок із соціальнонормативним аспектом благополуччя; переконаність у доброті людей корелюватиме з вищим рівнем емоційного і соціально-нормативного благополуччя; наявність переконаності в цінності власного "Я" у структурі особистісних переконань позитивно взаємопов'язуватиметься з его-благополуччям.

- У певної частини опитаних, унаслідок дії соціальних обмежень, спричинених пандемією COVID-19, буде спостерігатися заниження рівня емоційного і гедоністичного благополуччя; збереження в цей період соціальної активності (або відсутність негативних переживань у зв'язку із браком соціальної активності, спілкування) позитивно відобразиться на різних аспектах благополуччя.

Дослідження проводилося шляхом письмового групового опитування респондентів за допомогою онлайнплатформи "Google forms". Передбачалося викорис- тання такого тестового інструментарію: шкали базових переконань Р. Янов-Бульмана [7]; методики діагностики суб'єктивного благополуччя особистості Р. М. Шаміонова, Т. В. Бескової [11]. Кількісна обробка здійснювалася за допомогою методів статистичної обробки даних: кореляційного аналізу (коефріцієнт кореляції $r$ Пірсона), t-критерію Стьюдента для незалежних вибірок. Для підрахунку використовувався статистичний пакет "SPSS 21.0".

Вибірка дослідження представлена 103 особами віком 18-26 років. У дослідженні взяли участь студенти, аспіранти і випускники факультету психології Київського національного університету імені Тараса Шевченка. Дослідження проводилося у 2020 році.

Результати дослідження та наукова дискусія. Результати дослідження дозволили: виявити особливості взаємозв'язку аспектів психологічного благополуччя і переконань як частини світогляду особистості; констатувати наявність відмінностей виявлення різних аспектів благополуччя і переконань у респондентів, для яких період пандемії COVID-19 мав негативні наслідки щодо якості життя і призвів до погіршення стану соціального фрункціонування, а також у респондентів, які не зазначили погіршення стану власного соціального функціонування.

Відповідно до першого дослідницького завдання було проаналізовано виявлені взаємозв'язки переконань особистості (у прихильності та справедливості світу, доброті людей, цінності "Я") із аспектами психологічного благополуччя (емоційним, екзистенційнодіяльнісним, его-благополуччям, гедоністичним, соціально-нормативним благополуччям, табл. 1).

таблиця 1

Взаємозв'язки аспектів благополуччя із переконаннями особистості

\begin{tabular}{|c|c|c|c|c|c|c|c|c|}
\hline \multirow{3}{*}{ Переконання } & $\mathbf{K} / \mathbf{K}^{*}$ & $\mathbf{p}^{* *}$ & K/K & $\mathbf{p}$ & \multirow{2}{*}{\multicolumn{2}{|c|}{\begin{tabular}{l|l} 
К/К & p \\
II. Ставлення \\
до інших \\
\end{tabular}}} & \multirow{2}{*}{\multicolumn{2}{|c|}{ 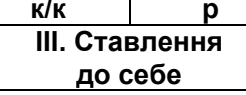 }} \\
\hline & \multicolumn{4}{|c|}{ І. Світоставлення } & & & & \\
\hline & \multicolumn{2}{|c|}{$\begin{array}{c}\text { 1. Прихильність } \\
\text { світу }\end{array}$} & \multicolumn{2}{|c|}{$\begin{array}{l}\text { 2. Справедливість } \\
\text { світу }\end{array}$} & \multicolumn{2}{|c|}{ 3. Доброта людей } & \multicolumn{2}{|c|}{ 4. Цінність "Я" } \\
\hline 1. Емоційне благополуччя &, $589^{\star \star}$ & 0,000 &, $426^{\star \star}$ & 0,000 &, $354^{\star \star}$ & 0,002 &, $435^{\star *}$ & 0,000 \\
\hline $\begin{array}{l}\text { 2. Екзистенційно-діяльнісне бла- } \\
\text { гополуччя }\end{array}$ &, $556^{\star *}$ & 0,000 & $452^{* \star}$ & 0,000 & $311^{* *}$ & 0,006 & $472^{* *}$ & 0,000 \\
\hline 3.Его-благополуччя &, $508^{\star *}$ & 0,000 &, $438^{\star *}$ & 0,000 &, $410^{\star *}$ & 0,000 &, $595^{\star *}$ & 0,000 \\
\hline 4.Гедоністичне благополуччя &, $376^{* *}$ & 0,000 & \multicolumn{2}{|c|}{ *** } & ,261* & 0,022 & \multicolumn{2}{|c|}{ *** } \\
\hline $\begin{array}{l}\text { 5.Соціально-нормативне } \\
\text { благополуччя }\end{array}$ &, $513^{\star *}$ & 0,000 &, $357^{\star *}$ & 0,001 & ,255* & 0,025 & \multicolumn{2}{|c|}{ *** } \\
\hline $\begin{array}{l}\text { Загальний рівень } \\
\text { благополуччя }\end{array}$ &, $657^{\star *}$ & 0,000 & $473^{\star *}$ & 0,000 & $413^{\star \star}$ & 0,000 &, $444^{* *}$ & 0,000 \\
\hline
\end{tabular}

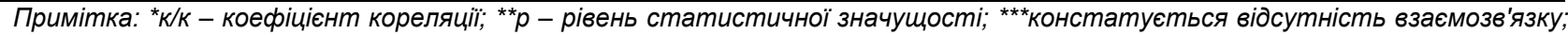
***ネБ - психологічне благополуччя.

Більшість констатованих у дослідженні взаємозв'язків переконань особистості із аспектами благополуччя $€$ прямими за спрямованістю і середніми за силою виявленнями; зазначаються слабкі зв'язки переконання в доброті людей із гедоністичним і соціальнонормативним благополуччям; найсильніші зв'язки можемо спостерігати між переконанням у прихильності світу з емоційним, екзистенційно-діяльнісним благополуччям, а також між переконанням у цінності "Я" і егоблагополуччям.

Відповідно до другого завдання дослідження було доведено наявність взаємозалежності загального рівня благополуччя і переконань особистості за допомогою проведеного регресійного аналізу, за результатами якого констатовано: загальний рівень благополуччя обумовлений переконаннями особистості у прихильності та справедливості світу, доброті людей і цінності власного "Я". Протестовану регресійну модель ми вважаємо задовільною - її коефріцієнт множинної детермі- нації становить 0,529 при рівні $p=0,000$. Отже, ми можемо зазначити значний вплив переконань у прихильності та справедливості світу, доброті людей і цінності "Я" на загальний рівень благополуччя особистості. Результат аналізу показав, що 52,9 \% дисперсії змінної "рівень благополуччя" обумовлено впливом означених переконань. Показник Дурбіна - Уотсона в цій моделі становить 1,84 , що дозволяє нам зробити висновок про нормальний розподіл даних.

Результати кореляційного і регресійного аналізу підтверджують більшість дослідницьких припущень. Наприклад, було доведено, що переконання особистості, які відображають особливості її світоставлення (прихильність і справедливість світу), ставлення до інших (переконання в доброті людей) і до себе (переконання в цінності "Я"), обумовлюють загальний рівень благополуччя. Отже, ці переконання можна вважати значущими світоглядними чинниками благополуччя особистості. 
Також було підтверджено другу частину гіпотези, хоча і не такою мірою, як передбачалося. Переконаність у цінності власного "Я" справді має доволі сильний взаємозв'язок з его-благополуччям. Переконання у прихильності та справедливості світу мають позитивний зв'язок із соціально-нормативним аспектом благополуччя, а переконаність у доброті людей корелює з вищим рівнем емоційного і соціально-нормативного благополуччя. Однак означені аспекти благополуччя мають більш виражені взаємозв'язки з іншими переконаннями особистості.

Найбільшою мірою взаємопов'язані із психологічним благополуччям у різних його аспектах переконання у прихильності світу і його справедливості (тобто переконання, які відображають особливості світоставлення особистості).

Найбільш сильні зв'язки із загальним рівнем благополуччя можемо констатувати стосовно переконання у прихильності світу $(r=0,657, p=0,000)$. Найбільшою мірою переконання у прихильності світу взаємопов'язане 3 такими аспектами благополуччя, як емоційний $(r=0,589, \quad p=0,000) \quad$ i екзистенційно-діяльнісний $(r=0,556, p=0,000)$. Менш вираженими $є$ зв'язки цього переконання із соціально-нормативним благополуччям $(r=0,513, p=0,000)$ i его-благополуччям $(r=0,508$, $p=0,000)$. Найслабшим $є$ зв'язок із гедоністичним благополуччям $(r=0,376, p=0,000)$.

Достатньо сильні взаємозв'язки із благополуччям демонструє переконання у справедливості світу. Ми зазначили кореляцію із загальним рівнем благополуччя $(r=0,473, p=0,000)$ і досить виражені кореляційні зв'язки 3 емоційним $(r=0,426, p=0,000)$, екзистенційнодіяльнісним $(r=0,452, p=0,000)$ і его-благополуччям $(r=0,438, \quad p=0,000)$. Взаємозв'язок із соціальнонормативним благополуччям трохи менше виражений $(r=0,357, p=0,001)$. Також констатуємо відсутність взаємозв'язку переконання у справедливості світу 3 гедоністичним благополуччям.

Результати дослідження дають підставу стверджувати, що переконання в цінності "Я" взаємопов'язане із благополуччям особистості. Зазначено кореляційний зв'язок із загальним рівнем благополуччя $(r=0,444$, $\mathrm{p}=0,000)$. Найбільшою мірою переконання в цінності "Я" взаємопов'язане $з$ его-благополуччям ( $r=0,595$, $p=0,000)$; також зазначимо значущі кореляції з екзистенційно-діяльнісним $(r=0,472, p=0,000)$ і емоційним благополуччям $(r=0,435, p=0,000)$. Взаємопов'язаність переконання в цінності "Я" із гедоністичним і соціальнонормативним благополуччям відсутня.

Також було визначено особливості взаємозв'язку між переконанням у доброті людей і благополуччям особистості. Найбільшою мірою переконання в доброті інших пов'язане 3 его-благополуччям $(r=0,410$, $p=0,000)$, а також із емоційним $(r=0,354, p=0,002)$ i екзистенційно-діяльнісним благополуччям $(r=0,311$, $\mathrm{p}=0,006)$. Кореляція між переконанням у доброті людей і загальним рівнем благополуччя середня за силою $(r=0,413, p=0,000)$. Окрім цього, виявлено слабкий взаємозв'язок цього переконання 3 гедоністичним $(r=0,261, p=0,022)$ і соціально-нормативним благополуччям $(r=0,255, p=0,025)$.

Таким чином, найбільшою мірою переживання благополуччя в різних аспектах забезпечується завдяки переконаності у прихильності світу, і частково - у справедливості навколишньої дійсності. Отже, саме сорормоване позитивне світоставлення, світоглядна спрямованість на позитивне сприйняття навколишньої дійсності допомагає особистості відчувати щастя і за- доволеність життям. Чим більше сформовані позитивне світоставлення, переконаність у прихильності та справедливості світу, тим більше емоційного задоволення від своєї діяльності та перебування в соціальному середовищі отримуватиме людина. Сприяє задоволеності життям і позитивне самоставлення, переконання в цінності власного "Я". Передусім таке переконання позитивно відображається на задоволеності самим собою і переживанні его-благополуччя, що цілком закономірно. Переконання в доброті інших людей позитивно відображається на переживанні егоблагополуччя, а також сприяє вищому рівню емоційної задоволеності життям.

Відсутність взаємозв'язку переконаності у справедливості світу і гедоністичного благополуччя можна легко інтерпретувати: таке світоглядне переконання ґрунтується на поняттях чесного взаємовигідного обміну між особистістю і світом (досягнення мають відповідати затраченим зусиллям), що не має нічого спільного 3 орієнтацією на отримання гедоністичного задоволення. Відсутність взаємозв'язку переконання в цінності "Я" з гедоністичним і соціально-нормативним благополуччям може бути пояснена таким чином: переконання самоцінності зароджується завдяки внутрішній роботі особистості над собою, самопізнанню, отже, воно з'являється за умови звернення особистості вглиб себе. Переживання гедоністичного і соціально-нормативного благополуччя, навпаки, може виникати за умови звернення особистості назовні (дослідження особливостей соціально-нормативного функціонування, пошук джерел отримання чуттєвого задоволення тощо). Отже, вектори цих аспектів благополуччя і переконання самоцінності можуть не збігатися.

Відповідно до третього завдання дослідження було виявлено особливості різних аспектів психологічного благополуччя і переконань залежно від особливостей соціального функціонування респондентів у період карантину. Попередньо за результатами опитування було перевірено наявність відмінностей у рівні психологічного благополуччя за трьома аспектами зміни життєдіяльності внаслідок пандемії COVID-19:

1) стан здоров'я (чи спостерігалося в респондентів погіршення фізичного благополуччя в цей період);

2) наявність фрінансових складнощів (чи було погіршення економічного благополуччя в період карантину);

3) зміна соціального функціонування й особливостей комунікації в бік погіршення.

Підтверджено наявність значущих відмінностей благополуччя залежно від особливостей соціального функціонування в період пандемії. 3 метою подальшого аналізу за означеним чинником уся вибірка була поділена на дві групи (табл. 2):

1. Група осіб, для яких період пандемії COVID-19 мав негативні наслідки щодо якості життя і призвів до погіршення стану соціального фрнкціонування (респонденти відмічають брак живого спілкування, негативні переживання у зв'язку зі скороченням кількості соціальних контактів і зміною якості спілкування внаслідок карантинних обмежень).

2. Група осіб, які не зазначили для себе погіршення стану соціального функціонування (не відчували емоційного дискомфорту і браку живого безпосереднього спілкування в період карантинних обмежень).

Було доведено наявність статистично значущих відмінностей між групами за такими параметрами: переконання у справедливості світу $(0,011$ при $р<0,05)$, цінності власного "Я" $(0,05$ при р<0,05), екзистенційнодіяльнісне благополуччя $(0,011$ при $p<0,05)$, егоблагополуччя $(0,018$ при $p<0,05)$. 
Таблиця 2

Особливості психологічного благополуччя і переконань особистості в період соціальних обмежень

\begin{tabular}{|c|c|c|c|}
\hline \multirow[b]{2}{*}{$\begin{array}{l}\text { Характеристика } \\
\text { для порівняння }\end{array}$} & \multicolumn{2}{|c|}{$\begin{array}{c}\text { Групи досліджуваних } \\
\text { (середні значення) }\end{array}$} & \multirow{2}{*}{$\begin{array}{c}\text { Значущість відмінно- } \\
\text { стей за критерієм } \\
\text { t Стьюдента } \\
\text { для незалежних } \\
\text { вибірок }\end{array}$} \\
\hline & $\begin{array}{c}\text { Група } 1 \\
\text { (констатують погіршення свого } \\
\text { соціального функціонування) }\end{array}$ & $\begin{array}{c}\text { Група } 2 \\
\text { (не констатують погіршення } \\
\text { свого соціального функціонування) }\end{array}$ & \\
\hline $\begin{array}{l}\text { 1. Переконання } \\
\text { у справедливості світу }\end{array}$ & 3,20 & 3,73 & 0,011 \\
\hline $\begin{array}{l}\text { 2. Переконання у цінності } \\
\text { власного "Я" }\end{array}$ & 3,85 & 4,34 & 0,050 \\
\hline $\begin{array}{l}\text { 3. Екзистенційно- } \\
\text { діяльнісне благополуччя }\end{array}$ & 3,34 & 3,73 & 0,011 \\
\hline 4. Его-благополуччя & 3,09 & 3,48 & 0,018 \\
\hline Кількість осіб & 60 & 43 & \\
\hline
\end{tabular}

Можемо констатувати таку тенденцію: показники за всіма зазначеними параметрами є вищими в осіб, які зазначили відсутність погіршення свого соціального функціонування в період пандемії; нижчими показники благополуччя $є$ в осіб, які переживають негативні емоції через брак живого спілкування й обмеження соціальної активності під час карантину.

Таким чином, представники другої групи (без погіршення соціального ффункціонування) продемонстрували вищі показники екзистенційно-діяльнісної задоволеності власним життям і его-благополуччя, а отже, відчували менше емоційного дискомфорту і негативних переживань через карантинні обмеження свого соціального функціонування. Як ми можемо побачити, у цієї групи також вищі показники переконаності у справедливості світу і цінності власного "Я". Імовірно, ці тенденції можна вважати взаємопов'язаними. Переконання у справедливості світу могло допомогти в умовах пандемії швидше змиритися з новими реаліями мінливого середовища, особливостями соціальної ситуації, яка склалася (обмеження культурного дозвілля, безпосереднього спілкування, комунікацій у сфрері професійного життя тощо). Проте примирення з новими умовами соціального функціонування мало допомогло адаптуватися до зміненого середовища: ефективно використовувати засоби для здійснення онлайн-комунікацій, професійної діяльності в дистанційному форматі й навіть організації власного культурного дозвілля з урахуванням карантинних обмежень. Успішність такої адаптації мала забезпечувати високий рівень екзистенційно-діяльнісного й его-благополуччя, оскільки особистість у цьому випадку показувала високу самоефективність у діяльнісному плані й мала всі підстави бути задоволеною собою і результатами власних зусиль.

Іншою виявилася ситуація з респондентами, якість соціального функціонування яких значно погіршилася в період пандемії. Отриманий результат слід спробувати інтерпретувати таким чином. Відсутність стійкої переконаності у справедливості світу в період карантинних обмежень могла зумовити переживання непокори, непримиримості щодо соціальної ситуації, яка склалася. Особистість, зосереджена значною мірою на таких негативних переживаннях, складніше адаптувалася до нових умов функціонування, що зумовило незадоволеність результатами своєї діяльності, заниження рівня екзистенційно-діяльнісного благополуччя. Відсутність сформованого переконання самоцінності в цих умовах також зіграла згубну роль: втрата в умовах карантинних обмежень джерела соціального позитивного підкріплення результатів своєї діяльності могла стати причиною нижчого рівня его-благополуччя. Наприклад, у докарантинних умовах особа могла отримувати підтвердження цінності свого "Я" від інших людей у процесі безпосередніх комунікацій (викладач хвалив роботу студента, начальник зазначав натхненну роботу колективу тощо). В умовах дистанційного навчання і роботи скоротилася кількість комунікацій (також спілкування в дистанційному форматі може бути більш формалізованим), а отже, і кількість можливостей підкріплення почуття самоцінності подібним чином. Для осіб із невираженим переконанням цінності "Я" зміна соціального функціонування в період пандемії могла стати негативним чинником его-благополуччя.

Висновки. Доведено наявність взаємозв'язків між переконаннями у прихильності та справедливості світу, доброті людей і цінності "Я" з такими аспектами благополуччя, як емоційний, екзистенційно-діяльнісний, егоблагополуччям; констатовано наявність зв'язку деяких означених переконань із гедоністичним і соціальнонормативним благополуччям. Виявлено, що наявність у особистості переконаності у прихильності та справедливості світу найбільшою мірою пов'язана з переживанням емоційного й екзистенційно-діяльнісного благополуччя. Наявність особистісних переконань у доброті людей і цінності власного "Я" найбільшою мірою пов'язана з вищим рівнем его-благополуччя.

Високому рівню благополуччя сприяють наявність у особистості переконань, які відображають позитивне світоставлення (переконаність у тому, що світ добрий і сповнений справедливості), ставлення до інших із вірою в їхню доброту і доброчесність, а також позитивне самоставлення, переконаність у цінності власного "Я". Було виявлено особливості прояву різних аспектів психологічного благополуччя і переконань особистості в період соціальних обмежень, спричинених пандемією COVID-19. 3'ясовано, що вищі показники екзистенційнодіяльнісного благополуччя й его-благополуччя були в осіб, які зазначили відсутність погіршення свого соціального функціонування в період пандемії. Також серед тих, у кого не відбулося погіршення соціального функціонування в період карантину, було виявлено вищі показники переконаності у справедливості світу і цінності власного "Я".

Актуальною темою подальших наукових пошуків $€$ визначення ширшого кола світоглядних переконань i дослідження їх взаємозв'язку із благополуччям особистості. Також перспективним напрямом досліджень могло б стати виявлення відмінностей переживання благополуччя в період пандемії серед різних вікових груп, представників різних професій і залежно від професійної затребуваності особи в умовах карантину.

Список використаної літератури

1. Кривега Л. Д. Мировоззренческие ориентации личности в условиях трансформации общества / Л. Д. Кривега. - Запорожье : ЗГУ, 1998.

2. Кузнецов О.І. Світогляд особистості як психологічна проблема / О. І. Кузнецов // Наук. вісник Херсон. держ. ун-ту. Серія : Психологічні науки. - Херсон : Херсон. держ. ун-т, 2019. - 1. - С. 41-48. 
3. Леонтьев Д. А. Мировоззрение как миф и мировоззрение как деятельность / Д. А. Леонтьев // Менталитет и коммуникативная среда в транзитивном обществе. - Томск : Томский гос. ун-т, 2004. - С. 11-29.

4. Литвинчук А. Особливості переживання почуття щастя молоддю і дорослими в умовах заходів протидії COVID-19 / А. Литвинчук, Т. Можаровська // Наук. часопис НПУ імені М. П. Драгоманова. Серія 12 : Психологічні науки. - 2020. - 10(55). - С. 47-57

5. Ляшенко О. А. Сутність феномена "ставлення" та його значущість у професійній діяльності психолога-консультанта [Електронний ресурс] / О. А. Ляшенко // Міжнар. наук. форум : соціологія, психологія, педагогіка, менеджмент. - 2012. - 9. - С. 184-191. - Режим доступу до ресурcy : http://nbuv.gov.ua/UJRN/Mnf_2012_9_28

6. Мясищев В. Н. Психология отношений : избр. психол. тр. ; под ред. А. А. Бодалева / В. Н. Мясищев. - М. : Изд-во Моск. психол.-соц. ин-та ; Воронеж : МОДЭК, 2011.

7. Падун М. А. Методика исследования базисных убеждений личности / М. А. Падун, А. В. Котельникова. - М., 2007.

8. Психологічне благополуччя особистості в період пандемії COVID19 / І. Г. Тітов, Т. Є. Тітова, К. В. Седих та ін. // Психологія і особистість: наук. журн. Ін-ту психології імені Г. С. Костюка НАПН України; Полтав. нац. пед. ун-ту імені В. Г. Короленка. - Київ; Полтава: ПНПУ імені В. Г. Короленка, 2020. - 2(18). - С. 55-76.

9. Федосенко Е. В. Жизнь после карантина: психология смыслов и коронавирус COVID-19 / Е. В. Федосенко // Психологические проблемы смысла жизни и акме. - 2020. - XXV. - С. 34-47.

10. Хмелько В.Е. Світогляд особи: психологічна структура і функції [Електронний ресурс] / В. Е. Хмелько // Філософська думка. - 1972. - 3. C. 30-38. - Режим доступу до ресурсу : http://old.kiis.com.ua/pub/svitos.pdf

11. Шамионов Р. М. Методика диагностики субъективного благополучия личности [Электронный ресурс] /Р. М. Шамионов, Т.В. Бескова // Психологические исследования. - 2018. - 11(60). - Режим доступа к ресуpcy : http://psystudy.ru/index.php/num/2018v11n60/1602-shamionov60.html

12. Юрьева Л. Н. Пандемия COVID-19: риски для психологического благополучия и психического здоровья [Электронный ресурс] / Л. Н. Юрьева, Т. И. Шустерман // Укр. вісник психоневрології. - 2020. - 28(2). - 5-10. Режим доступа к ресурсу : https://uvnpn.com.ua/upload/iblock/2cd/ 2cd19a17309d2de06cb09248ff7299f7.pdf

13. Використання соціальних мереж та суб'єктивне благополуччя в умовах пандемії COVID-19 /I. Ягіяєв, А. Новосельська, В. Келлер, М. Савич // Вісн. Київ. нац. ун-ту імені Тараса Шевченка. Серія : Психологія. $-2020 .-1(11)$. - С. 70-77

14. The psychological impact of the COVID-19 epidemic on college students in China / W. Cao, Z. Fang, G. Hou et al. // Psychiatry Research. 2020. $-287 .-112934$.

15. Koltko-Rivera M. The psychology of worldviews / M. Koltko-Rivera // Review of general psychology. - 2004. - 8(1). - P. 3-58.

References

1. Krivega, L. D. (1998) Mirovozzrencheskie orientacii lichnosti v uslovijah transformacii obshhestva [Worldview orientations of the individual in the context of the transformation of society]. Zaporozh'e : ZGU [in Russian].

2. Kuznetsov, O. I. (2019) Svitohliad osobystosti yak psykholohichna problema [Worldview of the individual as a psychological problem]. Naukovyi visnyk Khersonskoho derzhavnoho universytetu. Seriia Psykholohichni nauky - Scientific Bulletin of Kherson State University. Series: Psychological Sciences. Kherson, 1, 41-48 [in Ukrainian].

3. Leont'ev, D. A. (2004) Mirovozzrenie kak mif i mirovozzrenie kak deyatel'nost' [Worldview as a myth and worldview as an activity]. Mentalitet $i$ kommunikativnaya sreda $v$ tranzitivnom obshchestve - Mentality and communicative environment in a transitive society. Tomsk: Tomskij gosudarstvennyj universitet, 11-29 [in Russian]
4. Lytvynchuk, A., Mozharovska, T. (2020) Osoblyvosti perezhyvannia pochuttia shchastia moloddiu i doroslymy $v$ umovakh zakhodiv protydii COVID-19 [Features of experiencing feelings of happiness by young people and adults in the context of measures to combat COVID-19]. Naukovyi chasopys NPU imeni M.P. Drahomanova - Scientific journal of NPU M.P. Drahomanov, 10 (55), 47-57 [in Ukrainian]

5. Liashenko, O. A. (2012) Sutnist fenomenu "stavlennia" ta yoho znachushchist u profesiinii diialnosti psykholoha-konsultanta [The essence of the phenomenon of "attitude" and its significance in the professional activity of a counseling psychologist]. Mizhnarodnyi naukovyi forum: sotsiolohiia, psykholohiia, pedahohika, menedzhment - International scientific forum: sociology, psychology, pedagogy, management, 9, 184-191 [in Ukrainian]

6. Myasishchev, V. N. (2011) Psihologiya otnoshenij: izbr. psihol. tr. pod red. A. A. Bodaleva [Psychology of relations: selected psychological works]. M. : Izd-vo Mosk. psihol.-soc. in-ta; Voronezh : MODEK [in Russian].

7. Padun, M. A., Kotelnikova, A. V. (2007) Metodika issledovaniya bazisnyh ubezhdenij lichnosti [Methods of research of basic beliefs of the person]. Laboratorii psihologii i psihoterapii posttravmaticheskogo stressa IPRAN, Moskva [in Russian]

8. Titov, I. H., Titova, T. E., Sedykh, K. V., Giacomuzzi, S., Ertl, M., Rabe, M. (2020) Psykholohichne blahopoluchchia osobystosti v period pandemii COVID-19 [Psychological well-being of the individual during the COVID-19 pandemic]. Psykholohiia $i$ osobystist: nauk. zhurnal. Instytut psykholohii imeni H.S. Kostiuka NAPN Ukrainy - Psychology and personality: a scientific journal. G. S. Kostyuk Institute of Psychology of the National Academy of Pedagogical Sciences of Ukraine. Kyiv; Poltava, 2(18), 55-76 [in Ukrainian].

9. Fedosenko, E. V. (2020) Zhizn' posle karantina: psihologija smyslov i koronavirus COVID-19 [Life after quarantine: the psychology of meanings and the coronavirus COVID-19]. Psihologicheskie problemy smysla zhizni i acme - Psychological problems of the meaning of life and acme, XXV, 34-47 [in Russian].

10. Khmelko, V. E. (1972) Svitohliad osoby: psykholohichna struktura i funktsii [Personality worldview: psychological structure and functions]. Filosofska dumka - Philosophical thought, 3, 30-38 [in Ukrainian].

11. Shamionov, R. M., Beskova, T. V. (2018) Metodika diagnostiki subektivnogo blagopoluchiya lichnosti [Methods of diagnosing the subjective well-being of the individual]. Psihologicheskie issledovaniya - Psychological research, 60 [in Russian].

12. Yureva, L. N., Shusterman, T. I. (2020) Pandemiya COVID-19: riski dlya psihologicheskogo blagopoluchiya i psihicheskogo zdorovya [The COVID-19 pandemic: risks to psychological well-being and mental health]. Ukrainskyi visnyk psykhonevrolohii - Ukrainian Bulletin of Psychoneurology, 2, 5-10 [in Russian]

13. Yahiiaiev, I., Novoselska, A., Keller, V., Savych, M. (2020) Vykorystannia sotsialnykh merezh ta subiektyvne blahopoluchchia $v$ umovakh pandemii COVID-19 [Using social media and subjective well-being during COVID-19 pandemic]. Visnyk Kyivskoho natsionalnoho universytetu imeni Tarasa Shevchenka. Seriia: "Psykholohiia" - Bulletin of Taras Shevchenko National University of Kyiv. Series "Psychology", 1(11), 70-77 [in Ukrainian]

14. Cao, W., Fang, Z., Hou, G., Han, M., Xu, X., Dong, J., Zheng, J. (2020) The psychological impact of the COVID-19 epidemic on college students in China. Psychiatry Research, 287, 112934.

15. Koltko-Rivera, M. (2004) The psychology of worldviews. Review of general psychology, 8(1), 3-58.

Надійшла до редколегії 13.09.2020

Ksenia Gruzinova, Ph.D. student,

ORCID: 0000-0002-7800-1375

Taras Shevchenko National University of Kyiv, Kyiv, Ukraine

\section{PERSONAL BELIEFS AS A WORLDVIEW FACTOR OF PSYCHOLOGICAL WELL-BEING}

The article is devoted to researching the connections between aspects of psychological well-being and personal beliefs in the context of limitations in social functioning during a pandemic. The survey had conducted in the form of a written group survey of respondents. In the research, the following research methods were provided: R. Yanov-Bulman Basic Belief Scale; methods of diagnosing the individual's subjective well-being [11]. The results of the research were analyzed by using statistical processing methods.

The peculiarities of the connections between the aspects of well-being and personal beliefs were revealed. The presence of a person's belief in the benevolence and justice of the world is mostly due to the experience of emotional and existential well-being. The belief in the goodness of people and the value of one's own "self" in the structure of personal beliefs is associated mainly with a higher level of ego-well-being. It was proved that the general level of psychological well-being depends on beliefs: in commitment to the world, justice of the world, the kindness of people, and values of "self". The study made it possible to establish that the features of various aspects of psychological well-being and beliefs in the period of social constraints caused by the pandemic COVID-19. Higher indicators of existential-activity well-being and ego-well-being had the persons who noted the absence of deterioration of the social functioning during the pandemic. Also, among persons who did not experience a deterioration in social functioning during the quarantine period, higher rates of belief in the world's justice and the value of one's own "self" were found.

Thus, the role of basic beliefs as a worldview factor of well-being was proved, the peculiarities of their interdependence during the pandemic were studied. Empirical evidence has established the relationship between beliefs in the commitment and justice of the world, people's kindness, and the value of the "self" with various aspects of well-being.

Keywords: worldview, aspects of well-being, pandemic, benevolence of world, justice of world, world-attitude. 